\title{
Effects of rituximab treatment on the serum concentrations of vitamin $D$ and interleukins $2,6,7$, and 10 in patients with rheumatoid arthritis
}

This article was published in the following Dove Press journal:

Biologics:Targets and Therapy

31 January 2012

Number of times this article has been viewed

\author{
Eman Hasan' \\ Samuel Olusi ${ }^{2}$ \\ Adel Al-Awadhi ${ }^{3}$ \\ Khalid Mokaddem' \\ Prem Sharma ${ }^{4}$ \\ Sunila George 2 \\ 'Rheumatic Disease Unit, Al-Amiri \\ Hospital, Ministry of Health, Kuwait; \\ ${ }^{2}$ Department of Pathology, Faculty of \\ Medicine, Kuwait University, Kuwait; \\ ${ }^{3}$ Department of Medicine, Faculty of \\ Medicine, Kuwait University, Kuwait; \\ ${ }^{4}$ Computer Unit, Health Sciences \\ Center, Kuwait University, Kuwait
}

Correspondence: S O Olusi

Department of Pathology,

Faculty of Medicine, Kuwait University,

PO Box 24923, Al-Safat I 3 I I 0, Kuwait

Tel +965 24986230

Fax +965 25338905

Email olusoji@hsc.edu.kw
Background: Rituximab, a monoclonal antibody that selectively targets CD20-positive B-lymphocytes, is used for the treatment of patients with rheumatoid arthritis (RA) with an inadequate response or tolerance to tumor necrosis factor inhibitors. The objective of this study was to investigate the effects of rituximab treatment on the serum concentrations of vitamin $\mathrm{D}$, interleukin (IL) 2, IL-6, IL-7, and IL-10 in patients with rheumatoid arthritis (RA).

Methods: Forty-five patients, aged 25-78 years, were enrolled into a cohort prospective study. All patients were treated with intravenous rituximab. Disease activity score-28 (DAS-28) and serum concentrations of rheumatoid factor $(\mathrm{RF}), \mathrm{C}$-reactive protein (CRP), anticyclic citrullinated peptide (anti-CCP), erythrocyte sedimentation rate (ESR), health assessment questionnaire (HAQ), vitamin D, ILs 2, 6, 7, and 10 were estimated in the patients before and after treatment with rituximab.

Results: DAS-28, HAQ score, and serum concentrations of CRP, RF, anti-CCP, IL-2, IL-6, IL-7, IL-10, and ESR significantly decreased after treatment. All 45 patients had vitamin D deficiency before treatment and this did not significantly change after treatment. However no significant association was found among serum vitamin D concentration and any of the ILs.

Conclusion: We concluded from this study that although rituximab treatment of patients with RA significantly reduced their disease activity and serum concentrations of IL-2, IL-6, IL-7, and IL-10, it did not significantly alter their vitamin D status. Furthermore, no significant association was found among serum vitamin D concentration and any of the ILs.

Keywords: vitamin D, rituximab treatment, rheumatoid arthritis, interleukins

\section{Introduction}

Vitamin D, or cholecalciferol, is a steroidal hormone whose main function is the regulation of calcium homeostasis and bone formation and reabsorption. ${ }^{1}$ Recently, there has been a plethora of data on the noncalcitropic effects of vitamin D deficiency, separate from its known associations with increased fracture risk. ${ }^{2,3}$ As an example, vitamin D has been shown to alter the expression of more than 200 genes that affect cellular functions such as proliferation, differentiation, apoptosis, and angiogenesis. ${ }^{4}$ Thus vitamin D deficiency has been associated with various cancers. ${ }^{5-8}$

There is also a growing body of evidence that vitamin D is important in the initiation and propagation of a range of autoimmune diseases. ${ }^{9-11}$ This vitamin inhibits antibody secretion and autoantibody production in B cells. ${ }^{12}$ It has also been reported that synovium and lymphocytes from patients with rheumatoid arthritis (RA) express vitamin D receptor. The metabolically active form of the vitamin 1, 25 dihydroxyvitamin $\mathrm{D}_{3}(1,25-\mathrm{OHD})$ inhibits T-cell proliferation and prevents the release of Th-1 cytokines 
such as interleukin (IL)-2, interferon- $\gamma$ and tumor necrosis factor (TNF)- $\alpha .^{13}$

Thus, some but not all studies, have implicated low vitamin D intake as a risk factor in the development of RA. There are reports linking low vitamin D levels with increased disease activity and severity in patients with inflammatory arthritis. ${ }^{14-18}$ A number of studies have also demonstrated an inverse association between vitamin $\mathrm{D}$ and disease activity in patients with inflammatory arthritis but the results of these studies were not similar. ${ }^{19-21}$

Rituximab is a monoclonal antibody that selectively targets CD20-positive B lymphocytes. ${ }^{22}$ It is approved for the treatment of patients with RA with an inadequate response or tolerance to TNF inhibitors. The drug has been reported to provide significant and clinically meaningful improvements in disease activity in patients with longstanding RA who had been resistant to one or more anti-TNF therapies. ${ }^{22}$ Rituximab also inhibits the progression of structural damage in RA patients. ${ }^{23}$ Since this drug is a B-cell depleter, its use offers an opportunity to study the relationship between vitamin D status and some cytokines. The objectives of this study were therefore (1) to study the effect of rituximab treatment on vitamin D status in patients with RA and (2) to find out if there are any significant associations among serum vitamin D concentrations and proinflammatory cytokines (IL-2, IL-6, and IL-7) and anti-inflammatory cytokines (IL-10) to justify the acclaimed link of vitamin D to cytokine production.

\section{Patients and methods}

\section{Study patients}

Consecutive patients attending the Rheumatology Outpatient Clinic of Al-Amiri Teaching Hospital, Kuwait, who fulfilled the American College of Rheumatology (formerly the American Rheumatism Association) 1987 revised criteria ${ }^{24}$ were recruited for this study.

All patients first received one course of intravenous (IV) rituximab $1000 \mathrm{mg}$ and a second IV infusion of $1000 \mathrm{mg} 2$ weeks later after IV methylpredinosolone $100 \mathrm{mg}$ premedication. There was a washout period of at least 3 months before giving rituximab to those who had been on TNF- $\alpha$ blockers. All the patients were assessed before rituximab treatment and 6 months after the second dose of rituximab. The assessment consisted of counting the number of tender and swollen joints, estimation of the erythrocyte sedimentation rate (ESR) by the Westergren method, measurement of serum concentrations of C-reactive protein (CRP) by the nephelometric method, and evaluation of disease activity by the Disease Activity for 28 Joint Indices Score (DAS-28) ${ }^{25}$ Functional disability was measured by using the Arabic version of the Health Assessment Questionnaire (HAQ). ${ }^{26}$ All patients gave written informed consents and the study protocol was approved by the local ethics committee.

\section{Measurement of serum 25-OH-D concentrations}

Banked serum samples collected from the patients before and after treatment with rituximab were analyzed for $25-\mathrm{OH}-\mathrm{D}_{3}$ using the commercially available Immunodiagnostic Systems RIA kit (Immunodiagnostic Systems Ltd, Boldon Tyne and Wear, UK). This kit is a liquid phase radioimmunoassay kit for the quantitation of 25-hydroxy vitamin D and other hydroxylated metabolites in human serum or plasma. The sensitivity of the assay in our laboratory is $<3 \mathrm{nmol} / \mathrm{L}$ while the intra assay and inter assay coefficient of variations were 5.0 and $8.1 \%$, respectively. Insufficiency of $25-\mathrm{OH}-\mathrm{D}$ was defined as $<70 \mathrm{nmol} / \mathrm{L}(<30 \mathrm{ng} / \mathrm{mL})$ and deficiency as $<50 \mathrm{nmol} / \mathrm{L}(<20 \mathrm{ng} / \mathrm{mL})$. The normal range in our laboratory is $70-100 \mathrm{nmol} / \mathrm{L}$.

\section{Measurement of serum IL-2, IL-6, IL-7, and IL- I 0 concentrations}

The serum concentrations of these ILs in patients with RA before and after treatment with rituximab were estimated by using commercially available ELISA kits from

Table I Demographic and clinical characteristics of patients with active RA before treatment with rituximab

\begin{tabular}{ll}
\hline Characteristics & $\mathbf{n}=\mathbf{4 5}$ \\
\hline Gender ratio (M:F) & $1.1: 3.4$ \\
Age (years) & \\
$\quad$ Mean \pm SD & $48.9 \pm 1.78$ \\
$\quad$ Range & $(25-78)$ \\
Age at onset (years) & \\
$\quad$ Mean \pm SD & $36.6 \pm 11.4$ \\
$\quad$ Range & $(14-70)$ \\
RA duration (months) & \\
$\quad$ Median (interquartile) & 120 \\
$\quad$ Range & $(6-336)$ \\
Treatment & \\
$\quad$ Prednisolone (\%) & 20.7 \\
$\quad$ DMARDs (\%) & \\
$\quad$ One & 62.1 \\
$\geq 2$ & 13.8 \\
Previous anti-TNF (\%) & \\
I anti-TNF & 41.3 \\
2 anti-TNFs & 26.1 \\
3 anti-TNFs & 6.5 \\
\hline Abbreviations: RA, rheumo
\end{tabular}

Abbreviations: RA, rheumatoid arthritis; $M$, male; $F$, Female; SD, standard deviation; DMARDs, disease modifying anti-rheumatic drugs; TNF, tumor necrosis factor. 
Table 2 Clinical and laboratory parameters in patients with RA before and after treatment with rituximab

\begin{tabular}{lccc}
\hline Parameter & Before treatment & After treatment & P value \\
\hline DAS-28 & $6.28 \pm 0.24$ & $3.84 \pm 0.30$ & 0.001 \\
HAQ & $2.89 \pm 0.83$ & $1.52 \pm 0.61$ & 0.05 \\
Mean serum RF & $721.84 \pm 51.5$ & $93.32 \pm 30.3$ & 0.001 \\
Mean ESR $(\mathrm{mm} / \mathrm{hr})$ & $35.5 \pm 5.21$ & $18 \pm 6.35$ & 0.001 \\
Mean serum CRP $(\mathrm{mg} / \mathrm{dL})$ & $27.21 \pm 3.76$ & $11.54 \pm 1.92$ & 0.001 \\
Mean serum anti-CCP $(\mathrm{U} / \mathrm{mL})$ & $563.34 \pm 93.64$ & $350.75 \pm 113.25$ & 0.001 \\
\hline
\end{tabular}

Abbreviations: RA, rheumatoid arthritis; DAS, disease activity score; HAQ, health assessment questionnaire; RF, rheumatoid factor; ESR, erythrocyte sedimentation rate; CRP, C-reactive protein; anti-CCP, anti-cyclic citrullinated peptide.

IMMUNOTECH SAS (Marsielle, France). The instructions of the manufacturer of the kits were followed.

\section{Statistical analysis}

Data were analyzed using the Statistical Package for Social Sciences Software ([SPSS] v17.0; SPSS Inc, Chicago, IL). The variables were examined for normality with the Kolmogorov-Smirnov test, and descriptive statistics presented as appropriate. The differences between pretreatment and posttreatment values were compared using nonparametric MannWhitney or Kruskal-Wallis tests. Vitamin D concentrations were tested for any relationship with IL concentrations using Spearman correlation coefficient. The two-tailed probability $P<0.05$ was considered statistically significant.

\section{Results}

\section{Demographic characteristics}

A total of 45 patients with active RA were enrolled into the study. Of these, 34 (75.6\%) were females and 11 (24.4\%) were males (Table 1). The mean age of the patients was $48.9 \pm 1.78$ years with a range of $25-78$ years. The mean age at disease onset was $36.6 \pm 11.4$ years ranging from 14-70 years. The median RA duration was 10 years ranging from 6 months to 28 years. None of the patients had any significant dietary change that might affect vitamin D intake during the study. None of the patients had abnormal liver or renal functions that might affect the serum vitamin $\mathrm{D}$ concentrations.

\section{Clinical and laboratory parameters}

Table 2 shows a significant decrease in DAS-28, HAQ, serum concentrations of RF, CRP, anti-CCP, and ESR following treatment of RA patients with rituximab, suggesting that the drug was effective in reducing the inflammation of RA.

\section{Serum concentrations of vitamin D, IL-2, IL-6, IL-7, and IL- I0}

Figure 1 is a scatter plot showing the distribution of serum vitamin $\mathrm{D}$ concentrations in patients with $\mathrm{RA}$ before and after treatment with rituximab. All patients, before and after treatment, had serum vitamin D concentrations of less than $50 \mathrm{nmol} / \mathrm{L}$, the deficiency value in our laboratory. We did not include controls in this study because our aim was not to compare the prevalences of vitamin D deficiencies between patients with RA and the healthy population but to demonstrate the effect of rituximab treatment on vitamin D status. Figure 1 also shows that rituximab treatment did not significantly alter the status of vitamin D in patients with RA.

Table 3 shows that the mean serum concentrations of IL-2, IL-6, IL-7, and IL-10 significantly fell in patients with RA following treatment with rituximab. For example, serum IL-2 concentration fell from $52.56 \pm 6.29 \mathrm{pg} / \mathrm{mL}$ before treatment to $8.77 \pm 1.81 \mathrm{pg} / \mathrm{mL}$ after treatment while IL-7 fell from $146.63 \pm 9.23 \mathrm{pg} / \mathrm{mL}$ before treatment to $68.71 \pm 11.63$ $\mathrm{pg} / \mathrm{mL}$ after treatment.

\section{Association among serum vitamin D concentration and serum ILs before and after treatment with rituximab}

Table 4 shows that there were no significant associations among serum vitamin D concentration and serum IL-2,

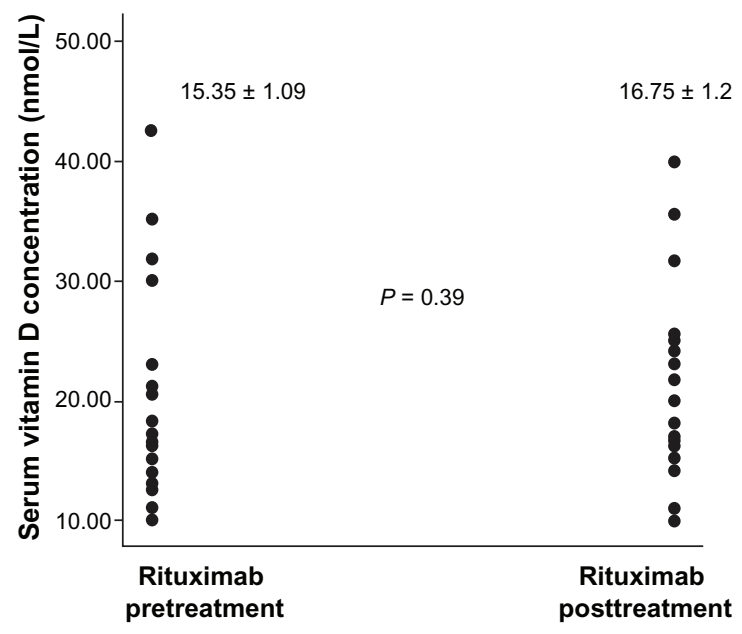

Figure I Scatter plot of vitamin D in patients with rheumatoid arthritis before and after treatment with rituximab. 
Table 3 Serum concentrations of vitamin D, IL-2, IL-6, IL-7, and IL-I0 in patients with RA before and after treatment with rituximab

\begin{tabular}{lccl}
\hline Analyte & $\begin{array}{l}\text { Before treatment } \\
(\text { mean } \pm \text { SD) }\end{array}$ & $\begin{array}{l}\text { After treatment } \\
(\text { mean } \pm \text { SD) }\end{array}$ & P value \\
\hline Serum vitamin D $(\mathrm{nmol} / \mathrm{L})$ & $15.35 \pm 1.09$ & $16.75 \pm 1.2$ & 0.39 \\
Serum IL-2 $(\mathrm{pg} / \mathrm{mL})$ & $52.56 \pm 6.29$ & $8.77 \pm 1.8 \mathrm{I}$ & $0.000 \mathrm{I}$ \\
Serum IL-6 $(\mathrm{pg} / \mathrm{mL})$ & $34.56 \pm 5.01$ & $21.32 \pm 2.99$ & 0.01 \\
Serum IL-7 $(\mathrm{pg} / \mathrm{mL})$ & $146.63 \pm 9.23$ & $68.71 \pm 11.63$ & $0.00 \mathrm{I}$ \\
Serum IL- I0 $(\mathrm{pg} / \mathrm{mL})$ & $32.26 \pm 6.01$ & $17.21 \pm 2.84$ & 0.01 \\
\hline
\end{tabular}

Abbreviations: IL, interleukin; RA, rheumatoid artritis; SD, standard deviation.

IL-6, IL-7, and IL-10 in patients with RA before and after treatment with rituximab.

\section{Discussion}

Although our objectives in this study did not include the investigation of the prevalence of vitamin D deficiency in patients with RA (and this was why we did not include any healthy controls), it is important to note that all 45 patients with RA had vitamin D deficiency before treatment. This finding is in accord with the almost pandemic vitamin D hypovitaminosis reported all over the world in general ${ }^{26,27}$ and in patients with RA in particular. ${ }^{28-30}$

The second important result from this study was that treatment of RA patients with rituximab did not alter their vitamin D status. To the best of our knowledge, this is the first report of the effect of rituximab treatment on serum vitamin $\mathrm{D}$ concentrations in patients with $\mathrm{RA}$. It was surprising that rituximab did not affect vitamin $\mathrm{D}$ status since vitamin $\mathrm{D}$ has been reported to inhibit antibody secretion and $\mathrm{T}$ cell proliferation. ${ }^{12,13}$ Rituximab is known to deplete $\mathrm{B}$ cells that produce antibodies. Therefore one would have expected that rituximab treatment would cause a significant reduction in serum vitamin $\mathrm{D}$ concentration. Why this was not so is not clear but further investigations on the relationship between vitamin $\mathrm{D}$, antibody production by $\mathrm{B}$ cells, and

Table 4 Association among serum vitamin $D$ concentration and serum ILs in patients with RA before treatment with rituximab

\begin{tabular}{lll}
\hline Serum ILs & $\begin{array}{l}\text { Associations with } \\
\text { serum vitamin D }\end{array}$ & Comments \\
\hline IL-2 & $r=0.05$ & No significant association \\
& $P=0.75$ & \\
IL-6 & $r=0.036$ & No significant association \\
& $P=0.82$ & No significant association \\
IL-7 & $r=-0.003$ & \\
& $P=0.98$ & No significant association \\
IL-10 & $r=-0.03$ & \\
& $P=0.85$ &
\end{tabular}

Abbreviations: IL, interleukin; RA, rheumatoid arthritis. cytokine serum concentrations need to be carried out on a large population.

The third important result of this study was that rituximab treatment of patients with RA significantly reduced their disease activity and their serum concentrations of RF, CRP, anti-CCP, and ESR. In this study, we found significant reductions in the serum concentrations of proinflammatory interleukins such as IL-2, IL-6, and IL-7. The reduction in disease activity in RA after treatment with rituximab might be due to the reductions in these proinflammatory ILs. It was surprising to find that treatment with rituximab in patients with RA also reduced their serum concentrations of IL-10, an anti-inflammatory IL. This might be due to the fact that rituximab depletes all B lymphocytes. The long term effect of this reduction in patients treated with rituximab is not known.

Perhaps the most important finding in this study was that the serum concentration of vitamin D was not significantly associated with serum concentration of either IL-2, IL-6, IL-7, or IL-10. These findings contradict the reports that vitamin $\mathrm{D}$ downregulates the production of several cytokines such as IL-2, IL-6, IL-12, interferon- $\gamma$, TNF- $\alpha$, and TNF- $\beta$ in in vitro studies. ${ }^{31,32}$ Our results, however, were in agreement with those of Vilarrasa et $\mathrm{al}^{33}$ who recently reported that no significant associations were found amongst 25-OHD and plasma concentrations of IL-18 and other cytokines. Further studies on larger sample sizes of healthy populations are needed to investigate the associations among serum vitamin D and IL concentrations.

\section{Conclusion}

We discovered from our study that treatment of RA patients with rituximab did not significantly alter their already depleted vitamin D status, although it significantly reduced their indices of inflammation and their serum concentrations of IL-2, IL-6, IL-7, and IL-10.

\section{Disclosure}

The authors report no conflicts of interest in this work. 


\section{References}

1. Arnson Y, Amital H, Shoenfeld Y. Vitamin D and autoimmunity: new aetiological and therapeutic considerations. Ann Rheum Dis. 2007;66: 1137-1142.

2. Looker AC, Pfeiffer CM, Lacher DA, Schleicher RL, Picciano MF, Yetley EA. Serum 25-hydroxyvitamin D status of the US population: 1988-1994 compared with 2000-2004. Am J Clin Nutr. 2008;88: 1519-1527.

3. Cherniack EP, Levis S, Troen BR. Hypovitaminosis D: a widespread epidemic. Geriatrics. 2008;63:24-30.

4. Cutolo M. Vitamin D and autoimmune rheumatic diseases. Rheumatology. 2009;48:210-212.

5. Krishnan AV, Trump DL, Johnson CS, Feldman D. The role of vitamin D in cancer prevention and treatment. Endocrinol Metab Clin North Am. 2010;39:401-418.

6. Anderson LN, Cotterchio M, Vieth R, Knight JA. Vitamin D and calcium intakes and breast cancer risk in pre- and postmenopausal women. Am J Clin Nutr. 2010;91:1699-1707.

7. Karlsson S, Olausson J, Lundh D, et al. Vitamin D and prostate cancer: the role of membrane initiated signaling pathways in prostate cancer progression. J Steroid Biochem Mol Biol. 2010;121:413-416.

8. Tse AK, Zhu GY, Wan CK, Shen XL, Yu ZL, Fong WF. 1alpha, 25Dihydroxyvitamin D3 inhibits transcriptional potential of nuclear factor kappa B in breast cancer cells. Mol Immunol. 2010;47:1728-1738.

9. Holick MF. High prevalence of vitamin D inadequacy and implications for health. Mayo Clin Proc. 2006;81:353-373.

10. Cutolo M, Otsa K, Palino S, Yprus M, Veldi T, Seriolo B. Vitamin D involvement in rheumatoid arthritis and systemic lupus erthymatosus. Ann Rheum Dis. 2009;67:446-447.

11. Pérez-López FR. Vitamin D and its implications for musculoskeletal health in women: an update. Maturitas. 2007;58:117-137.

12. Ritterhouse LL, Crowe SR, Niewold TB et al. Vitamin D deficiency is associated with an increased autoimmune response in healthy individuals and in patients with systemic lupus erthematosus. Ann Rheum Dis. 2011;(70):1569-1574.

13. Ranganathan P. Genetics of bone loss in rheumatoid arthritis - role of vitamin D receptor polymorphisms. Rheumatology. 2009;48(4): 342-346.

14. Liao KP, Alfredsson L, Karlson EW. Environmental influences on risk for rheumatoid arthritis. Curr Opin Rheumatol. 2009;21(3):279-283.

15. Nielen MM, van Schaardenburg D, Lems WF, et al. Vitamin D deficiency does not increase the risk of rheumatoid arthritis. Arthritis Rheum. 2006;54:3719-3720.

16. Costenbader KH, Feskanich D, Holmes M, Karlson EW, BenitoGarcia E. Vitamin D intake and risks of systemic lupus erythematosus and arthritis in women. Ann Rheum Dis. 2008;67:530-535.

17. Merlino LA, Curtis J, Mikuls TR, Cerhan JR, Criswell LA, Saag KG. Vitamin D intake is inversely associated with rheumatoid arthritis: results from the Iowa Women's Health Study. Arthritis Rheum. 2004;50:72-77.
18. Patel S, Farragher T, Berry J, Bunn D, Silman A, Symmons D Association between serum vitamin D metabolite levels and disease activity in patients with early inflammatory polyarthritis. Arthritis Rheum. 2007;56:2143-2149.

19. Turhanoğlu AD, Güler H, Yönden Z, Aslan F, Mansuroglu A, Ozer C. The relationship between vitamin $\mathrm{D}$ and disease activity and functional health status in rheumatoid arthritis. Rheumatol Int. 2010;31: 911-914.

20. Craig SM, Yu F, Curtis JR, et al. Vitamin D status and its associations with disease activity and severity in African Americans with recentonset rheumatoid arthritis. J Rheumatol. 2010;37:275-281.

21. Braun-Moscovici Y, Toledano K, Markovits D, Rozin A, Nahir AM, Balbir-Gurman A. Vitamin D level: is it related to disease activity in inflammatory joint disease? Rheumatol Int. 2011;31:493-499.

22. Cohen SB, Emery P, Greenwald MW, et al. Rituximab for rheumatoid arthritis refractory to anti-tumor necrosis factor therapy: Results of a multicenter, randomized, double-blind, placebo-controlled, phase III trial evaluating primary efficacy and safety at twenty-four weeks. Arthritis Rheum. 2006;54:2793-2806.

23. Keystone E, Emery P, Peterfy CG, et al. Rituximab inhibits structural joint damage in patients with rheumatoid arthritis with an inadequate response to tumour necrosis factor inhibitor therapies. Ann Rheum Dis. 2009;68:216-221

24. Arnett FC, Edworthy SM, Bloch DA, et al. The American Rheumatism Association 1987 revised criteria for the classification of rheumatoid arthritis. Arthritis Rheum.1988;31:315-324.

25. Prevoo ML, van 't Hof MA, Kuper HH, van Leeuwen MA, van de Putte LB, van Riel PL. Modified disease activity scores that include twenty-eight-joint counts. Development and validation in a prospective longitudinal study of patients with rheumatoid arthritis. Arthritis Rheum. 1995;38:44-48.

26. Shehab D, Al-Jarallah K, Moussa MA. Validation of the Arabic version of the Health Assessment Questionnaire (HAQ) in patients with rheumatoid arthritis. Rev Rhum Engl Ed. 1998;65:387-392.

27. Gannagé-Yared MH, Tohmé A, Halaby G. Hypovitaminosis D: a major worldwide public health problem. Presse Med. 2001;(30):653-658.

28. Adams JS, Hewison M. Update in vitamin D. J Clin Endocrinol Metab. 2010;95:471-478.

29. Zold E, Szodoray P, Gaal J, et al. Vitamin D deficiency in undifferentiated connective tissue disease. Arthritis Res Ther. 2008;10:R123.

30. Damanhouri LH. Vitamin D deficiency in Saudi patients with systemic lupus erythematosus. Saudi Med J. 2009;30:1291-1295.

31. Mauricio D, Mandrup-Poulsen T, Nerup J. Vitamin D analogues in insulin-dependent diabetes mellitus and other autoimmune diseases: a therapeutic perspective. Diabetes Metab Rev. 1996;12:57-68.

32. Lemire JM. J Immunomodulatory actions of 1, 25-dihydroxyvitamin D3. Steroid Biochem Mol Biol. 1995;53:599-602.

33. Vilarrasa N, Vendrell J, Maravall J, et al. Is plasma $25(\mathrm{OH})$ D related to adipokines, inflammatory cytokines and insulin résistance in both a healthy and morbidly obese population? Endocrinology. 2010;38: 235-242.
Biologics: Targets \& Therapy

\section{Publish your work in this journal}

Biologics: Targets \& Therapy is an international, peer-reviewed journal focusing on the patho-physiological rationale for and clinical application of Biologic agents in the management of autoimmune diseases, cancers or other pathologies where a molecular target can be identified. This journal is indexed on PubMed Central, CAS, EMBase, Scopus

\section{Dovepress}

and the Elsevier Bibliographic databases. The manuscript management system is completely online and includes a very quick and fair peerreview system, which is all easy to use. Visit http://www.dovepress. $\mathrm{com} /$ testimonials.php to read real quotes from published authors. 